\title{
HUBUNGAN ANTARA STATUS SOSIAL EKONOMI DENGAN PRESTASI BELAJAR MAHASISWA PROGRAM STUDI PENDIDIKAN AKUNTANSI FKIP UNIVERSITAS PGRI PALEMBANG
}

\author{
Oleh: Depi Pramika ${ }^{1}$, Chandra Kurniawan², Widya Agustina, Reni Muniarti \\ (UNIVERSITAS PGRI PALEMBANG) \\ 1) depi.neynda0506@gmail.com, ${ }^{2)}$ chandrakurniawan79@gmail.com
}

\begin{abstract}
Abstrak
Tujuan penelitian ini adalah untuk mengetahui hubungan antara status sosial ekonomi dengan prestasi belajar mahasiswa Program Studi Pendidikan Akuntansi FKIP Universitas PGRI Palembang. Metode yang digunakan dalam penelitian ini adalah metode deskriptif korelasional dengan pendekatan kuantitatif. Populasi dan sampel dalam penelitian ini adalah seluruh mahasiswa semeseter 8 angkatan tahun 2013 yang masih aktif kuliah berdasarkan Kartu Hasil Studi (KHS) terakhir berjumlah 73 mahasiswa. Data yang digunakan dalam penelitian ini adalah data sekunder dan primer dengan tekhnik pengumpulan data melalui angket dan dokumentasi. Analisis data dilakukan dengan analisis korelasi menggunakan alat bantu Statistical Product and Service Solutions (SPSS ver. 24.0). Hasil penelitian berdasarkan uji hipotesis melalui statistik korelasi Kendall's Tau dan Spearman's Rho dengan bantuan SPSS 24.0 menunjukkan tidak ada hubungan antara status sosial ekonomi orang tua dengan prestasi belajar mahasiswa. Hal ini disebabkan karena status soasial ekonomi orang tua baik dari indikator pendidikan, pekerjaaan, dan penghasilan berada pada kategori rendah dan sangat rendah, sehingga mendorong mahasiswa untuk dapat meningkatkan prestasi belajarnya dengan harapan setelah mereka lulus bisa mendapatkan pekerjaan yang lebih baik dari orang tuanya dengan begitu status sosial ekonomi keluarga akan meningkat.
\end{abstract}

Kata Kunci: Status Sosial Ekonomi, Prestasi Belajar Mahasiwa, Pendidikan Akuntansi

\section{RELATIONSHIP BETWEEN THE ECONOMIC SOCIAL STATUS WITH STUDENT LEARNING ACHIEVEMENT STUDY PROGRAM OF ACCOUNTING EDUCATION FKIP UNIVERSITY PGRI PALEMBANG}

\begin{abstract}
Abstrack
This research is aim to the relationship between socioeconomic status and student achievement of Accounting Education Studies Program at PGRI Palembang University. The method used in this research is descriptive correlational method with quantitative approach. The population and sample in this study were all students of the 8th graders of the year 2013 who are still active lectures based on the latest Card Study Results (KHS) last amounted to 73 students. The data used in this study is secondary and primary data with data collection techniques through questionnaires and documentation. Data analysis was performed by correlation analysis using Statistical Product and Service Solutions (SPSS ver. 24.0). The result of the research based on
\end{abstract}


hypothesis test through Kendall's Tau and Spearman's Rho correlation statistic with SPSS 24.0 showed no relation between socioeconomic status of parents and student's achievement. This is because the parental economic status of both education, employment and income indicators is low and very low, encouraging students to improve their learning achievement in the hope that after graduation they can get a better job from their parents the socioeconomic status of the family will increase.

Keywords: Social Economic Status, Student Learning Achievement, Accounting Education

\section{PENDAHULUAN}

Keberhasilan

dalam

pembangunan nasional sangat didukung oleh jumlah penduduk yang besar, tetapi jika penduduk yang besar itu memiliki kualitas yang rendah maka akan menjadi beban bagi pembagunan nasional. Oleh sebab itu untuk menunjang keberhasilan pembangunan nasional dalam menangani permasalahan penduduk pemerintah tidak saja mengarahkan pada upaya pengendalian jumlah penduduk tapi juga menitikberatkan pada peningkatan kualitas sumber daya manusianya. Bahkan dalam perekonomian yang semakin maju kegiatan-kegiatan ekonomi memerlukan tenaga terdidik (Sukirno, 2012:365). Selain itu penduduk khususnya generasi penerus bangsa dituntut untuk dapat bersaing dalam menghadapi era globalisasi yang semakin maju.

Menyongsong era globalisasi yang semakin maju pemerintah telah berusaha semaksimal mungkin melakukan berbagai upaya untuk lebih mengutamakan pendidikan. Upaya tersebut hampir mencakup segala komponen pendidikan seperti perubahan kurikulum, buku pedoman dan sarana belajar lainnya. Penyempurnaan sistem pendidikan, penataan organisasi dan usaha-usaha lain yang berkaitan dengan peningkatan pendidikan.

Dalam rangka meningkatkan pendidikan, peran perguruan tinggi sebagai pendidik para calon sarjana dalam bidang keilmuan tertentu, maka pada perguruan tinggi ditetapkan berbagai fakultas dengan jurusan dan program studi sesuai dengan minat dan keahlian mahasiswa, sehingga lulusan yang dihasilkan oleh perguruan tinggi dapat menjadi seorang yang ahli profesional dalam suatu ilmu atau bidang keahlian serta sanggup mengabdikannya guna kepentingan masyarakat dan bangsa. 
Melihat tujuan yang ingin dicapai tersebut maka mahasiswa dituntut untuk dapat menguasai bidang studinya yang dibebankan, khususnya yang menyangkut bidang keahliannya, karena diharapkan lulusan yang dihasilkan dapat memenuhi sejumlah kompetensi belajar yang ada pada perguruan tinggi. Kompetensi belajar merupakan pencerminan dari prestasi belajar yang dicapai oleh siswa setelah melakukan usaha belajar. Terpenuhi atau tidaknya kompetensi tersebut dapat dilihat dari hasil studinya yang berupa daftar nilai yang mencantumkan prestasi belajar mahasiswa tersebut.

Belajar adalah usaha memperoleh kepandaian atau ilmu. Dengan demikian wujud kepandaian dan ilmu yang dimiliki seseorang setelah melakukan kegiatan belajar dapat disebut sebagai prestasi belajar. Menurut Herman Hudojo (Cleopatra, 2015:175), prestasi belajar merupakan pengetahuan yang dimiliki seseorang setelah mengalami proses pembelajaran dan hal itu diperlihatkan dengan kemampuan memecahkan masalah dengan menerapkan pengetahuan yang diperoleh dari proses pembelajaran.

Prestasi belajar menjadi salah satu parameter keberhasilan belajar peserta didik di sekolah (Komara, 2016:37). Prestasi belajar adalah taraf keberhasilan seorang peserta didik dalam mempelajari materi pelajaran di sekolah yang dinyatakan dalam bentuk skor yang diperoleh dari hasil tes mengenai sejumlah materi pelajaran tertentu. Menurut Syah (2015:216) prestasi belajar merupakan hasil belajar atau hasil penilaian secara menyeluruh. Hal ini diperkuat oleh pendapatnya Sudjana (2009:22), prestasi belajar adalah kemampuan-kemampuan yang dimiliki peserta didik setelah peserta didik tersebut menerima pengalaman belajarnya.

Prestasi belajar dapat dipengaruhi oleh banyak faktor salah satunya yaitu status sosial ekonomi orang tua karena keberhasilan suatu penyelenggaraan pendidikan di perguruan tinggi sangat tergantung oleh status sosial ekonomi. Problem pendidikan di perguruan tinggi adalah menuntut setiap keluarga khususnya orang tua untuk dapat menyiapkan segala biaya yang berhubungan dengan kebutuhan pendidikan anaknya. Biaya yang dikeluarkan oleh orang tua bersumber dari pekerjaannya, dan tentu besar kecilnya penghasilan yang didapat dari pekerjaan tersebut dipengaruhi oleh pendidikan. Hal ini akan memberi dampak bagi usaha meningkatkan prestasi belajar mahasiswa. 
Sesuai yang dikemukakan oleh Slameto (2015:60) Faktor-faktor yang dapat mempengaruhi prestasi belajar meliputi faktor keluarga (cara orang tua mendidik, relasi antara anggota keluarga, suasana rumah, keadaan ekonomi keluarga, pengertian orang tua, dan latar belakang kebudayaan). Menurut Sugihartono, dkk (2007:30) bahwa "Status sosial ekonomi orang tua meliputi tingkat pendidikan orang tua, pekerjaan orang tua, dan penghasilan orang tua". Sementara menurut Usman (2004:126) bahwa "Status sosial ekonomi tercermin pada pemikiran atau penguasaan kekayaan, prestige dan kekuasaan ekonomi. Status sosial merupakan sekumpulan hak dan kewajiban yang dimiliki seseorang dalam masyarakatnya". Sehingga dapat diasumsikan dengan adanya kemampuan ekonomi, keluarga akan mampu menyiapkan segalah hal yang berkaitan dengan penyedian fasilitas belajar bagi anak serta biaya lain yang dibutuhkan anak dalam berbagai kebutuhan pendidikan di sekolah/perguruan tinggi.

Berdasarkan hasil wawancara dengan mahasiswa program studi pendidikan akuntansi FKIP Universitas PGRI Palembang didapatkan informasi mengenai peranan ekonomi keluarga dalam menentukan prestasi belajar. Karena paradigma pendidikan kita saat ini tidak berpusat pada guru/dosen melainkan pada siswa/mahasiswa, dimana setiap mahasiswa dituntut aktif dalam perkulihan terutama dalam penyelesaian tugas-tugas yang diberikan dosen dalam rangka memahami materimateri perkuliahan, dan semua itu berhubungan dengan status sosial ekonomi. Status sosial ekonomi orang tua rata-rata bervariasi, dilihat dari tingkat pendidikan, pekerjaan, dan pendapatan. Berdasarkan latar belakang tersebut di atas tujuan dari penelitian ini adalah untuk mengetahui hubungan antara status sosial ekonomi dengan prestasi belajar mahasiswa Program Studi Pendidikan Akuntansi FKIP Universitas PGRI Palembang.

\section{METODE PENELITIAN}

Menurut Sugiyono metode penelitian merupakan cara ilmiah untuk mendapatkan data dengan tujuan dan kegunaan tertentu. Metode penelitian adalah cara yang digunakan oleh peneliti dalam mengumpulkan data penelitiannya (Arikunto, 2010:203). Metode yang digunakan dalam penelitian ini adalah metode deskriptif 
korelasional dengan pendekatan kuantitatif. Hal ini dikarenakan peneliti ingin mencari hubungan- hubungan baru yang terdapat pada suatu permasalaha yang luas dan kompleks. Populasi dari penelitian adalah seluruh mahasiswa semeseter 8 angkatan tahun 2013 yang masih aktif kuliah berdasarkan Kartu Hasil Studi (KHS) terakhir berjumlah 73 mahasiswa. Adapun sampelnya yaitu seluruh populasi, hal ini didasarkan pada pendapat Arikunto (2010:174-175) yang menyatakan bahwa, sampel adalah sebagian atau wakil populasi yang akan diteliti. Dan menurut pendapat Surakhmad dalam Riduwan (2010:65), apabila ukuran populasi kurang lebih dari 100, maka pengambilan sampel sekurang-kurangnya $50 \%$ dari ukuran populasi.

Agar penelitian ini dapat mencapai tujuan yang tepat dan memperoleh informasi yang selengkaplemgkapnya, maka teknik yang digunakan untuk memperoleh informasi tersebut antara lain dengan menggunakan:

\section{Dokumentasi}

Dokumentasi adalah barangbarang tertulis seperti buku-buku, majalah, dokumen, peraturan-peraturan, notulen rapat, catatan harian, dan sebagainya, maupun bukan berwujud tulisan yang berupa benda-benda peninggalan seperti prasasti dan simbolsimbol (Arikunto, 2010:201-202). Dalam penelitian ini dokumentasi digunakan untuk memperoleh data mengenai jumlah siswa dan indek prestasi komulatif mahasiswa semester 8 angkatan 2013 yang masih aktif kuliah dilihat dari KHS tahun akademik 2016/2017.

\section{Angket}

Kuesioner atau angket adalah sejumlah pertanyaan tertulis yang digunakan untuk memperoleh informasi dari responden dalam arti laporan tentang pribadinya, atau hal-hal yang ia ketahui (Arikunto, 2010:194). Dalam penelitian ini angket digunakan dalam rangka pengumpulan data mengenai status sosial ekonomi, yaitu variabel bebas (pendidikan, pekerjaan, dan pendapatan orang tua). Jenis angket yang digunakan yaitu angket langsung tertutup dengan bentuk pilihan ganda dan isian. Dalam angket ini bentuk pilihan ganda sudah tersedia struktur pertanyaan yang telah disediakan jawabannya dan responden tinggal 
memilih jawaban yang sesuai, serta mengisi beberapa pertanyaan dalam bentuk isiin. Angket terdiri dari 31 butir/soal pertanyaan, namun setelah dilakukan uji validitas dan reliabilitas data angket yang valid dan reliabel hanya 19 butir. Selanjutnya angket yang sudah valid dan reliabel tersebut disebarkan kepada 73 responden (pada saat penyebaran angket 6 responden tidak mengembalikan angket jadi jumlah responden hanya 66) untuk memperoleh data-data dari jawaban responden.

\section{HASIL DAN PEMBAHASAN}

Penelitian dilakukan di Universitas PGRI Palembang Fakultas Keguruan dan Ilmu Pendidikan Program Studi Pendidikan Akuntansi. Mahasiswa yang diambil pada saat melakukan penelitian ini adalah mahasiswa semester 8 (delapan) angkatan 2013 tahun ajaran 2016/2017. Pemilihan mahasiswa semester 8 (delapan) dikarenakan dalam penelitian ini, peneliti ingin melihat hubungan status sosial ekonomi orang tua yang mencakup indikator pendidikan, pekerjaan, dan pendapatan orang tua dengan prestasi belajar mahasiswa, dan mahasiwa yang masih aktif kuliah dengan tingkatan semester yang paling tinggi adalah mahasiswa semester 8 (delapan). Selain itu juga prestasi belajarnya sudah mencakup seluruh semester, dari semester 1 (satu) sampai dengan semester 8 (delapan) yang diberi nama indeks prestasi komulatif (IPK).

\section{Hasil Penelitian}

\section{Deskripsi Data Hasil Angket}

Deskripsi data angket mengenai status sosial ekonomi per indikator menunjukkan bahwa persentase tertinggi adalah $66,11 \%$ dan skor terendah 14,52\%, banyaknya data adalah 66 responden. Berikut tabel persentase status sosial ekonomi per indikator:

\section{Tabel 1. Persentase Status Sosial}

Ekonomi Per Indikator

\begin{tabular}{|c|l|c|}
\hline No. & \multicolumn{1}{|c|}{ Indikator } & Persentase \% \\
\hline 1. & $\begin{array}{l}\text { Pendidikan } \\
\text { orang tua }\end{array}$ & 14,52 \\
\hline 2. & $\begin{array}{l}\text { Pekerjaan orang } \\
\text { tua }\end{array}$ & 19,37 \\
\hline 3. & $\begin{array}{l}\text { Pendapatan } \\
\text { orang tua }\end{array}$ & 66,11 \\
\hline \multicolumn{2}{|c|}{ Jumlah } & 100 \\
\hline
\end{tabular}

Sumber: Diolah dari hasil penelitian

Berdasarkan tabel 1 di atas dapat disimpulkan bahwa indikator yang paling tinggi adalah pendapatan orang tua dengan persentase $66,11 \%$, dimana penghasilan orang tua mahasiswa baik 
ayah maupun ibu sebagian besar berada diantara Rp.0 - Rp3.749.999 dengan kategori sangat rendah. Sedangkan indikator yang paling rendah adalah pendidikan orang tua dengan nilai persentase sebesar $14,52 \%$. Pendidikan orang tua mahasiswa ini sebagian besar merupakan lulusan SMP-SMA sederajat dengan kategori tinggi. Adapun untuk pekerjaan sebagian besar ayah bekerja sebagai petani, sementara ibu sebagai petani dan ibu rumah tangga dengan kategori pekerjaan orang tua sangat rendah.

Angket yang telah dideskripsikan, selanjutnya dianalisis untuk megetahui persentase jawaban angket mahasiswa seluruh butir, lihat tabel 2 di bawah ini:

Tabel 2. Distribusi Frekuensi Status Sosial Ekonomi

Orang Tua

\begin{tabular}{|c|c|c|c|}
\hline Interval & Frekuensi & Persentase & Kategori \\
\hline $81 \%-100 \%$ & 0 & $0 \%$ & Sangat Tinggi \\
\hline $61 \%-80 \%$ & 7 & $10,61 \%$ & Tinggi \\
\hline $41 \%-60 \%$ & 56 & 84,85 & Rendah \\
\hline $21 \%-40 \%$ & 3 & 4,54 & Sangat Rendah \\
\hline Jumlah & $\mathbf{6 6}$ & $\mathbf{1 0 0 \%}$ & \\
\hline
\end{tabular}

Sumber: Diolah dari hasil penelitian

Dari tabel di atas diketahui bahwa status sosial ekonomi orang tua menunjukkan sebanyak $10,61 \%$ berada pada kategori tinggi, $84,85 \%$ berada pada kategori rendah, dan 4,54\% berada pada kategori sangat rendah. Artinya hampir seluruh status sosial ekonomi orang tua berada pada kategori rendah. Dengan jumlah data 66 mahasiswa diketahui rata-rata persentase angket sebesar 51,64\% dengan kategori rendah.

Dalam diagram dapat terlihat sebagai berikut: 


\section{Gambar 1. Distribusi Frekuensi Status Sosial Ekonomi Orang Tua (Dalam Pembulatan)}

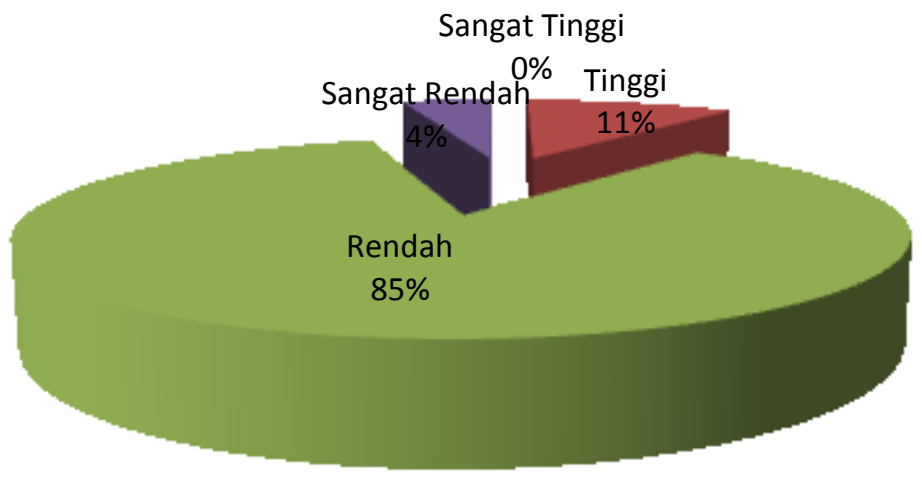

Deskripsi Hasil Prestasi Belajar

Deskripsi hasil prestasi belajar mahasiswa yang diambil dari indek prestasi komulatif berdasarkan data yang diperoleh dari program studi pendidikan akuntansi yang tertera pada kartu hasil studi mahasiswa menunjukkan IPK tertinggi 3,82 dan
IPK terendah 2,61, serta didapat harga rata-rata yaitu 3,27.

Data prestasi belajar yang telah dideskripsikan, selanjutnya dianalisis. Adapun analisisnya dapat dilihat dari distribusi frekuensi nilai rata-rata prestasi belajar mahasiswa sebagai berikut:

Tabel 3. Distribusi Frekuensi Nilai Rata-Rata Prestasi Belajar Mahasiswa

\begin{tabular}{|c|c|c|c|}
\hline Interval & Frekuesni & Persentase & Kategori \\
\hline $3,51-4,00$ & 5 & $7,58 \%$ & Dengan Pujian \\
\hline $2,75-3,50$ & 60 & $90,91 \%$ & Sangat Memuaskan \\
\hline$\leq 2,74$ & 1 & $1,51 \%$ & Memuaskan \\
\hline Jumlah & $\mathbf{6 6}$ & $\mathbf{1 0 0 \%}$ & \\
\hline
\end{tabular}

Sumber: Diolah dari hasil penelitian

Dari tabel di atas diketahui bahwa prestasi belajar mahasiswa menunjukkan sebanyak 7,58\% berada pada kategori dengan pujian, 90,91\% berada pada kategori sangat memuaskan, dan $1,51 \%$ berada pada kategori memuaskan. Artinya hampir seluruh prestasi mahasiswa berada pada 


kategori atau predikat sangat Dalam diagram dapat terlihat
memuaskan.

\section{Gambar 2. Distribusi Frekuensi Nilai Rata-rata \\ Prestasi Belajar Mahasiswa Per Kategori/Predikat}

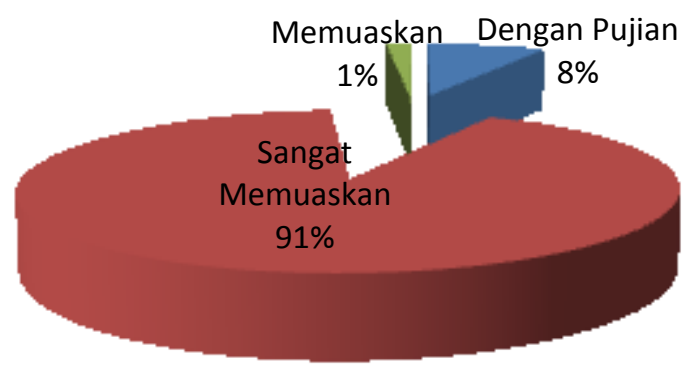

\section{Analisis Hasil Uji Hipotesis (Analisis}

\section{Data dengan Statistik)}

Dalam penelitian ini penulis menggunakan teknik analisis data statistik parametris dengan Korelasi Pearson bila data terdistribusi normal sedangkan bila data tidak terdistribusi normal menggunakan statistik Non parametris dengan korelasi Spearman's Rho Dan Kendall's Tau. Analisis data dilakukan dengan bantuan program komputer Statistical Product and Service Solutions (SPSS ver. 24.0). Hasil perhitungan statistik disajikan dalam bentuk deskriptif untuk memaparkan deskripsi data dengan menggunkan analisis korelasi. Uji korelasi ini berguna untuk melihat kekuatan atau besar hubungan anatara variabel status sosial ekonomi dengan prestasi belajar mahasiswa.

\section{Normalitas Data}

Sebelum melakukan uji korelasi terlebih dahulu dilakukan uji normalitas data untuk mengetahui apakah kedua data terdistribusi normal atau tidak. Adapun output SPSS uji normalitas data adalah sebagai berikut: 


\section{Tabel 4. Output SPSS Uji Normalitas Data Status Sosial Ekonomi dan Prestasi Belajar}

One-Sample Kolmogorov-Smirnov Test

\begin{tabular}{|c|c|c|c|}
\hline & & $\begin{array}{l}\text { Variabel Status } \\
\text { Sosial Ekonomi } \\
\text { Orang Tua } \\
\end{array}$ & $\begin{array}{c}\text { Variabel } \\
\text { Prestasi Belajar }\end{array}$ \\
\hline $\mathrm{N}$ & & 66 & 66 \\
\hline \multirow[t]{2}{*}{ Normal Parameters ${ }^{a, b}$} & Mean & 51.6364 & 3.2694 \\
\hline & Std. Deviation & 6.66249 & .18711 \\
\hline \multirow[t]{3}{*}{ Most Extreme Differences } & Absolute & .112 & .096 \\
\hline & Positive & .112 & .096 \\
\hline & Negative & -.062 & -.078 \\
\hline Test Statistic & & .112 & .096 \\
\hline Asymp. Sig. (2-tailed) & & $.038^{\mathrm{c}}$ & $.200^{\mathrm{c}, \mathrm{d}}$ \\
\hline \multicolumn{4}{|c|}{$\begin{array}{l}\text { a. Test distribution is Normal. } \\
\text { b. Calculated from data. } \\
\text { c. Lilliefors Significance Correction. } \\
\text { d. This is a lower bound of the true significance. }\end{array}$} \\
\hline
\end{tabular}

Untuk mengetahui normalitas data dapat dilihat dari signifikan kenormalan data pada baris Asymp. Sig.(2-tailed) pada masing-masing kolom. Jika angka lebih dari 0,05; artinya data terdistribusi normal (Sufren dan Natanael, 2014:75). Pada tabel di atas terlihat nilai signifikansi variabel status sosial ekonomi adalah 0,038< 0,05 . Artinya, data ini terdistribusi tidak normal. Untuk variabel prestasi belajar, nilai signifikansi sebesar $0,200>0,05$. Artinya data ini terdistribusi normal. Karena salah satu data terdistribusi tidak normal, maka persyaratan untuk statistik parametris dengan Korelasi
Pearson tidak cocok digunakan, sehingga digunakan statistik non parametris dengan korelasi Spearman's Rho Dan Kendall's Tau (Sufren dan Natanael, 2014:79-81; Sugiyono, 2011:227).

\section{Pengujian Statistik}

Berdasarkan uji normalitas diketahui salah satu data terdistribusi tidak normal, sehingga statistik yang digunakan adalah statistik non parametrik dengan korelasi Spearman's Rho Dan Kendall's Tau. Adapun ouput dari SPSS uji Spearman's Rho Dan Kendall's Tau adalah sebagai berikut: 
Tabel 5. Output SPSS Uji Spearman's Rho, Kendall's Tau Status Sosial Ekonomi

\begin{tabular}{|c|c|c|c|c|}
\hline \multicolumn{5}{|c|}{ dan Prestasi Belajar } \\
\hline & & & $\begin{array}{l}\text { Variabel Status } \\
\text { Sosial Ekonomi } \\
\text { Orang Tua }\end{array}$ & $\begin{array}{c}\text { Variabel } \\
\text { Prestasi Belajar }\end{array}$ \\
\hline \multirow{6}{*}{$\begin{array}{l}\text { Kendall's } \\
\text { tau_b }\end{array}$} & \multirow{3}{*}{$\begin{array}{l}\text { Variabel Status Sosial } \\
\text { Ekonomi Orang Tua }\end{array}$} & Correlation Coefficient & 1.000 & -.025 \\
\hline & & Sig. (2-tailed) & & .769 \\
\hline & & $\mathrm{N}$ & 66 & 66 \\
\hline & \multirow[t]{3}{*}{ Variabel Prestasi Belajar } & Correlation Coefficient & -.025 & 1.000 \\
\hline & & Sig. (2-tailed) & .769 & \\
\hline & & $\mathrm{N}$ & 66 & 66 \\
\hline \multirow{6}{*}{$\begin{array}{l}\text { Spearman } \\
\text { 's rho }\end{array}$} & \multirow{3}{*}{$\begin{array}{l}\text { Variabel Status Sosial } \\
\text { Ekonomi Orang Tua }\end{array}$} & Correlation Coefficient & 1.000 & -.017 \\
\hline & & Sig. (2-tailed) & & .893 \\
\hline & & $\mathrm{N}$ & 66 & 66 \\
\hline & \multirow[t]{3}{*}{ Variabel Prestasi Belajar } & Correlation Coefficient & -.017 & 1.000 \\
\hline & & Sig. (2-tailed) & .893 & \\
\hline & & $\mathrm{N}$ & 66 & 66 \\
\hline
\end{tabular}

Untuk mengetahui apakah data mempunyai hubungan yang signifikan atau tidak dapat dilihat pada baris Sig. (2-tailed) baik pada Kendall's tau maupun Spearman's rho, dimana jika angka lebih dari 0,05; artinya, tidak ada hubungan yang signifikan antar variabel (Sufren dan Natanael, 2014:83). Pada tabel 5 di atas terlihat pada Kendall's tau, nilai Sig. (2-tailed) (p) sebesar $0,769>0,05 ;$ artinya, tidak ada hubungan yang signifikan antara status sosial ekonomi dengan prestasi belajar. Kemudian pada Spearman's rho, nilai Sig. (2-tailed) (p) sebesar 0,893 >0,05; artinya, tidak ada hubungan yang signifikan antara status sosial ekonomi dengan prestasi belajar.

Berdasarkan hasil korelasi Kendall's tau, tidak ada hubungan yang signifikan antara status sosial ekonomi dengan prestasi belajar $(0,769>0,05)$. Begitu juga, berdasarkan hasil korelasi Spearman's rho, tidak ada hubungan yang signifikan antara status sosial ekonomi dengan prestasi belajar $(0,893$ $>0,05)$. Artinya, tinggi atau rendahnya status sosial ekonomi orang tua, belum tentu dapat meningktakan prestasi belajar mahasiswa. Sebaliknya, bagus atau tidaknya prestasi mahasiswa, belum tentu dia berasal dari orang tua yang status sosial ekonominya rendah.

\section{Pembahasan}

Berdasarkan hasil angket penelitian didapat frekuensi status sosial ekonomi orang tua menunjukkan sebanyak 10,61\% (7 mahasiswa) berada pada kategori tinggi, $84,85 \% \quad(56$ 
mahasiswa) berada pada kategori rendah, dan 4,54\% (3 mahasiswa) berada pada kategori sangat rendah. Artinya hampir seluruh status sosial ekonomi orang tua berada pada kategori rendah. Adapun rata-rata status sosial ekonomi orang tua dari skor persentase angket 51,64\% diaktegorikan rendah.

Prestasi belajar mahasiswa menunjukkan sebanyak $7,58 \% \quad(5$ mahasiswa) berada pada kategori dengan pujian, 90,91\% (60 mahasiswa) berada pada kategori sangat memuaskan, dan 1,51\% (1 mahasiswa) berada pada kategori memuaskan. Artinya hampir seluruh prestasi mahasiswa berada pada kategori atau predikat sangat memuaskan. Terbukti dengan rata-rata prestasi belajar mahasiswa dikategorikan sangat memuaskan yaitu 3,27.

Dari hasil penelitian melalui statistik korelasi Kendall's Tau dengan bantuan SPSS 24.0 didapat $r(66)=$ 0,$03 ; p>0,05$, sehingga menunjukkan tidak ada hubungan antara status sosial ekonomi orang tua dengan prestasi belajar mahasiswa. Begitu juga, berdasarkan hasil korelasi dengan Spearman's Rho menggunakan bantuan SPSS 24.0 didapat $r(66)=-0,02 ; p>$ 0,05 , sehingga menunjukkan tidak ada hubungan antara status sosial ekonomi orang tua dengan prestasi belajar mahasiswa. Artinya, tinggi atau rendahnya status sosial ekonomi orang tua, belum tentu dapat meningktakan prestasi belajar mahasiswa. Sebaliknya, bagus atau tidaknya prestasi belajar mahasiswa, belum tentu dia berasal dari orang tua yang status sosial ekonominya rendah ataupun tinggi. Hal ini bisa dilihat dari data prestasi belajar mahasiswa yang semuanya berada pada kategori sangat memuaskan dan dengan pujian. Hanya ada satu mahasiswa yang mempunyai prestasi belajar dengan katagori memuaskan atau dibawah 3,0, padahal status sosial ekonomi orang tua hampir semuanya berasal dari status sosial ekonomi yang rendah. Hal ini menunjukkan bahwa status sosial ekonomi orang tua tidah mempunyai hubungan yang signifikan dengan prestasi belajar mahasiswa angkatan 2013 program studi pendidikan akuntansi FKIP Universitas PGRI Palembang. Tidak adanya hubungan tersebut disebabkan oleh beberapa faktor, yaitu sebagai berikut:

1. Mahasiswa berasal dari orang tua yang mempunyai pendidikan dengan lulusan SMP-SMA Sederajat dan lulusan SD/Ibtidaiyah baik ayah maupun ibu, hanya beberapa yang mempunyai orang 
tua dengan lulusan Diploma I/II/III/Akademi/Universitas. Hal ini mendorong mahasiswa untuk mempunyai pendidikan yang lebih tinggi dari orang tuanya, sehingga dapat meningkatkan status sosial ekonomi keluarga, dan salah satu cara yang dapat mereka lakukan adalah dengan meningkatkan prestasi belajarnya.

2. Mahasiswa berasal dari orang tua yang mempunyai pekerjaan dengan kategori rendah dan sangat rendah. Hal ini juga menyebabkan mahasiswa untuk meningkatkan prestasi belajarnya sehingga ketika mereka lulus dari universitas nanti mereka bisa mendapatkan pekerjaan yang lebih tinggi dari orang tuanya. Dan tentu hal ini akan bisa meningkatkan status sosial ekonomi keluarga mereka.

3. Kebanyakan mahasiswa berasal dari orang tua dengan penghasilan sangat rendah yaitu antara Rp.0 Rp.3.749.999. Sementara dengan penghasilan ini orang tua mereka tidak hanya untuk memenuhi kebutuhan pendidikan mereka tetapi juga kebutuhan pendidikan saudara mereka yang lain, ditamabah dengan kebutuhan ekonomi lainnya, sehingga membuat mereka terdorong untuk meningkatkan prestasi belajarnya dengan tujuan agar jerih payah orang tua mereka tidak sia-sia dan ketika mereka lulus dengan prestasi belajar yang baik bisa bekerja dengan penghasilan yang lebih besar dari orang tuanya sehingga dapat membantu memenuhi ekonomi keluarga dan juga dapat meningkatkan status sosial ekonomi keluarga. Selain itu, ada juga mahasiswa yang kadangkadang membantu ekonomi keluarganya dengan bekerja untuk memenuhi kebutuhan pendidikannya, sehingga mereka dapat merasakan susahnya mencari uang dan memenejemen waktu antara kuliah dan kerja, dan hal ini tentu membuat mereka lebih terdorong untuk meningkatkan prestasi belajarnya.

\section{KESIMPULAN}

Berdasarkan hasil penelitian yang penulis lakukan dengan judul "hubungan status sosial ekonomi dengan prestasi belajar mahasiswa program studi pendidikan akuntansi FKIP Universitas PGRI Palembang”, 
maka dapat disimpulkan sebagai berikut:

1. Berdasarkan hasil analisis dan pembahasan data angket, didapat persentase rata-rata status sosial ekonomi orang tua sebesar 51,64\% dengan kategori rendah.

2. Berdasarkan hasil analisis IPK (prestasi belajar) mahasiswa menunjukkan hampir seluruh prestasi mahasiswa berada pada kategori atau predikat sangat memuaskan. Terbukti dengan ratarata prestasi belajar mahasiswa sebesar 3,27 dengan kategori sangat memuaskan.

3. Berdasarkan hasil uji hipotesisi melalui statistik korelasi Kendall's Tau dengan bantuan SPSS 24.0 didapat $r(66)=-0,03 ; p>0,05$, sehingga menunjukkan tidak ada hubungan antara status sosial ekonomi orang tua dengan prestasi belajar mahasiswa. Begitu juga, berdasarkan hasil korelasi dengan Spearman's Rho menggunakan bantuan SPSS 24.0 didapat $r(66)=$ $-0,02 ; p>0,05, \quad$ sehingga menunjukkan tidak ada hubungan antara status sosial ekonomi orang tua dengan prestasi belajar mahasiswa. Artinya, tinggi atau rendahnya status sosial ekonomi orang tua, belum tentu dapat meningktakan prestasi belajar mahasiswa. Sebaliknya, bagus atau tidaknya prestasi belajar mahasiswa, belum tentu dia berasal dari orang tua yang status sosial ekonominya rendah ataupun tinggi

\section{DAFTAR PUSTAKA}

Arikunto, Suharsimi. 2010. Prosedur Penelitian Suatu Pendekatan Praktik. Jakarta: Rineka Cipta.

Cleopatra, Maria. 2015. Pengaruh Gaya Hidup Dan Motivasi Belajar terhadap Hasil belajar Matematika. Jurnal Formatif. Volume 5, Nomor 2, 2015. Hal 168-181 ISSN:2088-351X. (Online) dari http://journal.lppmunindra.ac.id/in dex.php/Formatif/article/viewFile/ 336/321, diakses, 27 Maret 2017. 
Komara, Indra Bangkit. 2016. Hubungan antara Kepercayaan Diri dengan Hasil belajar dan Perencanaan Karir Siswa. Jurnal Psikopedagogia. Vol. 5, No. 1, Hal. 33-42. ISSN 2301-6167. (Online) dari http://journal.uad.ac.id/index.php/ PSIKOPEDAGOGIA, diakses 21 Maret 2017

Riduwan. 2010. Belajar Mudah Penelitian untuk Guru-Karyawan dan Peneliti Pemula. Bandung: Alfabeta.

Slameto. 2015. Belajar dan Faktorfaktor yang Mempengaruhi. Jakarta: PT Rineke Cipta.

Sudjana, 2009. Metode Statistik. Bandung: Tarsito.

Sufren dan Yonathan Natanael. 2014. Belajar Otodidak SPSS Pasti Bisa. Jakarta: Elex Media Komputindo

Sugihartono,dkk. 2007. Psikologi Pendidikan. Yogyakarta: UNY Pers.

Sugiyono. 2009. Metode Penelitian Kuantitatif, Kualitatif dan $R \& D$. Bandung: Alfabeta.

\section{Statistik} Nonparametris untuk Penelitian. Bandung: Alfabeta

Sukirno, Sadono. 2012. Mikro Ekonomi Teori Pengantar Edisi Ketiga. Jakarta: PT. Raja Grafindo Persada.
Usman, Sunyoto. 2004. Sosiologi Sejarah, Teori dan Metodologi. Yogyakarta: CIRED.

Syah, Muhibbin. 2015. Psikologi Belajar. Jakarta: Rajawali Pers 